\title{
FORESTRY PROFESSIONALS' AWARENESS OF THE EU TIMBER REGULATION IN THE FEDERATION OF BOSNIA - HERZEGOVINA
}

\author{
Poznavanje odredbi EU Uredbe o drvetu od strane šumarskih stručnjaka \\ u Federaciji Bosne i Hercegovine
}

\author{
Dženan Bećirović ${ }^{1}$, Sabina Delić ${ }^{1}$, Mersudin Avdibegović ${ }^{1}$, Bruno Marić ${ }^{1}$, \\ Senka Mutabdžija Bećirović ${ }^{1}$, Špela Pezdevšek Malovrh ${ }^{2}$
}

\begin{abstract}
Illegal logging and related trade represent one of the most important forest-related issues at international policy scene. In 2002, the European Union had initiated establishment of regional initiatives on preventing trade of illegally harvested wood, well known as FLEGT process. Other important segment of European Union efforts is adoption of legally-binding Regulation No. 995/2010 - EU Timber Regulation (EUTR) that prohibits import of illegally harvested wood and their products into EU. Bosnia-Herzegovina is country with economy in transition and with relatively slow progress toward EU integration process, while rising of awareness on need for prevention and combat with illegal activities and corruption represent one of the mayor challenges for its society. This paper analyse forestry professionals' awareness of the EU Timber Regulation in the Federation of Bosnia-Herzegovina as precondition for planning further steps on improving human and institutional capacities in forest sector to prevent and combat with illegal activities. In order to conduct the analysis of forestry professionals' awareness on EUTR, survey was conducted among currently employed forestry professionals in forest sector of the FB-H. Results revealed that employed forestry professionals in the FB-H have different level of awareness on EUTR. Therefore, creation and consistent implementation of informational forest policy instruments are needed in order to increase capacities of forestry professionals related to elements of EUTR implementation process. Efforts on prevention and combat with illegal activities in forest sector should involve implementation of mix of forest policy instruments directed toward harmonization of forest policy in the FB-H with EUTR requirements based on active participation of forestry professionals that are aware of EUTR implementation process and its potential influences on forest and woodprocessing sectors of the FB-H.
\end{abstract}

Key words: Illegal logging, European Union, FLEGT, EUTR, forestry professionals, Federation of Bosnia -Herzegovina

\footnotetext{
${ }^{1}$ University of Sarajevo, Faculty of Forestry

${ }^{2}$ University in Ljubljana, Biotechnical Faculty, Department of Forestry and Renewable Forest Resources
} 


\section{INTRODUCTION - Uvod}

Illegal logging and related trade represent one of the most important forestrelated issues at international policy scene. Importance of these issues, their scale and variety of consequences are manifested through significant percentage of deforestation and forest degradation that are direct outcome of increased illegal activities in forest sector. Since illegal logging and related trade are complex societal issues with lot of causally related economic, political and social factors, their comprehensive understanding represent an initial step in developing and implementing appropriate policy instruments for prevention and combat (TACCONI, 2008).

Although the European Union (hereinafter EU) has no common forest policy, issue of illegal logging and related trade represent common problem of its Member States (COMmISSION OF THE EC, 2008). Therefore, the EU have been undertaking various measures for preventing and combating with forest-related illegal activities in order to support sustainable forest management. In 2002, together with the World Bank, the EU had initiated establishment of regional initiatives on preventing trade of illegally harvested wood, well-known as the FLEGT process (Forest Law Enforcement, Governance and Trade). Signing of Voluntarily Partnership Agreements (VPAs) between producing/exporting countries and the EU represents main tool for implementing FLEGT Action plan. Other important segment for realization of FLEGT process is adoption of legally-binding EU Regulation No. 995/2010, well-known as EU Timber Regulation (hereinafter EUTR), at the territory of Member States. Main goal of EUTR, which was adopted on October $20^{\text {th }} 2010$, is to prohibit import of illegally harvested wood and wooden products in EU. The term "Illegally harvested" means harvested in contravention of the applicable legislation in the country of harvest or origin of wood and wooden products (EUTR, ARTICLE 1). EUTR put particular attention on importance of measures that are undertaken by operators as well as the obligations of the Member States. Having this in mind, EUTR will influence trade of wood products at the EU market as well as the producers for whom EU countries represent final markets of their products.

For Bosnia-Herzegovina (hereinafter B-H), EU-accession process implies implementation of fundamental socio-political reforms, reform of public sector and harmonization of legislative framework with demands of EU policies and market. Same also holds for forest sector albeit, similar to other sectors, it has been influenced by highly decentralised administrative structure of B-H. Such situation has particularly strong influence in case of the Federation of Bosnia-Herzegovina (hereinafter FB-H). Although significant number of wood processors is export-oriented toward EU market, slow progress in prevention and combat with illegal activities in forest sector could cause significant problems in exporting wood products from the FB-H to the EU market. This is particularly the case since accession of Croatia to the EU after which B-H becomes EU's bordering country. 


\section{Dženan Bećirović, Sabina Delić, Mersudin Avdibegović, Bruno Marić, Senka Mutabdžija Bećirović, Špela Pezdevšek Malovrh}

Having in mind that B-H is country with economy in transition and with relatively slow progress in EU integration process, rising awareness on need for prevention and combat with illegal activities and corruption represent one of the mayor challenges for its society (UNODC, 2011). As with the other sectors in the FB-H, improvement of internal human and institutional capacities of forest sector represent one of the most important steps in prevention and combat with forest-related illegal activities. Therefore, this paper intends to analyse forestry professionals' awareness of the EUTR in the FB-H as precondition for planning further steps on improving human and institutional capacities in forest sector to prevent and combat with illegal activities.

Despite of the fact that forest and wood-processing sectors represent important branches of domestic economy (VTK B-H, 2014) and that EU accession is one of the leading political priorities of $\mathrm{B}-\mathrm{H}$, domestic forest policy research have no consistent study which is dealing with issue on illegal logging and harmonisation of forest policy and legislation with EU demands. Few authors have been dealing with the issue on harmonisation of domestic forest policy with EU acquis communautaire more generally through analysis of forest certification (AVDIBEGOVIĆ, 2001; AVDIBEGOVIĆ ET AL., 2003), dynamism of regulatory forest policy instruments (AVDIBEGOVIĆ ET AL., 2006; BRAJIĆ ET AL., 2011) and cross-sectoral perception of internationally accepted forest governance concept (MUTABDŽIJA, 2013). On the other side, illegal activities in forest sector of $\mathrm{B}-\mathrm{H}$ have been analysed in the reports of international nongovernmental organisations (WWF, 2008; REC, 2010). These reports emphasised that illegal activities represent serious threat of forest sector in B-H.

Having in mind that implementation of EUTR has started quite recently, it is expected that issues of harmonisation of national forest policies with its requirements will be actualised. This paper represents initial step in overall analysis of harmonization of forest policy in the FB-H with EU requirements related to trade of wood and wood products. The main research question of this paper is: What is the level of awareness of forestry professionals in the FB-H on EUTR and its requirements? Based on answers of the respondents, mix of forest policy instruments has been proposed. Such mix of forest policy instruments should represent a basis for improvement of human and institutional capacities for prevention and combat with illegal logging in the FB-H. Apart from forestry professionals, results of this paper can be very useful for key forest policy decision makers as well as public administration responsible for forestry whose main tasks are to initiate and lead process of national forest policy harmonisation with EU acquis communautaire related to forestry.

\section{RESEARCH METHODS - Metode istraživanja}

Primary data for analysis of forestry professionals' awareness on EUTR were collected through survey conducted among currently employed forestry professionals in forest sector of the FB-H. For the purpose of data-collection, it was necessary to 
design appropriate questionnaire (that contained 8 closed-type questions), while survey was conducted whether by personal visit of the respondents or via e-mail communication. The questionnaire was designed in order to obtain basic sociodemographic information of target population (such as age and working experience of the respondents as well as type of institution of employment) and to provide data necessary for analysis of awareness on EUTR requirements in forest sector of the FB$\mathrm{H}$. The survey was conducted in the period from January to May 2013 among forestry professionals that are employed in public forest enterprises and public administration (Federal forest office or cantonal forest offices) in the FB-H. The database of currently employed forestry professionals, which was created for the purpose of GovoR project (The adaptation of national forest policy systems in South-East European countries (Bosnia-Herzegovina, Croatia, Macedonia and Serbia) to new modes of international forest governance), was used for respondents' selection. Database consisted names and contact details of 435 forestry professionals with university degree that are employed in cantonal forest enterprises, Federal forest office or cantonal forest offices. In order to precisely determine the level of awareness of forestry professionals on the EUTR and its requirements, it was decided to contact all identified respondents from the database. Furthermore, for the purpose of increasing response rate of respondents that were contacted via e-mail, TDM method (Dillman's Tailored Design Method) was utilised (DILlmAN, 2007; URQUHART AND COURTENEY, 2011). After finalising the survey, 435 questionnaires had been delivered to the potential respondents while 294 were adequately filled and returned to the researcher. The final response rate of this survey was $67 \%$. This response rate is in accordance to the findings of similar studies where the response rate of $58 \%$ were sufficient for the samples/population up to 500 respondents (NULTY, 2008) in order to provide the appropriate level of reliability of the conclusions and recommendations.

Collected data were inserted in the MS Excel and processed in SPSS version 18.00. The statistical analysis in this study was carried out by two-step process. Firstly, data were summarized by frequency distribution, selected measures of location and dispersion (mean and standard deviation) and cross-tabulation. The second phase of analysis involved construction of the logistic regression model (to assess which factors influence awareness on EUTR requirements), by means of Enter algorithm (FIELD, 2009). The dependent variable (Level of awareness on EUTR), for the selection equation was binary in nature, taking the value of " 1 " if the respondents were aware to EUTR requirements and " 0 " if it is opposite. The following independent variables were used in a model: age (AGE), working experience (EXP) and type of employment institution (INST). Before running the analysis, data were assessed for multicollinearity, using variation inflation factor (VIFs), which ensure that no high correlations exist when one independent variable is regressed on the other. The results of the diagnostics revealed that collinearity was not significant. 


\section{RESULTS AND DISCUSSION - Rezultati i diskusija}

\section{Basic socio-demographic characteristics of the respondents - Osnovne socio-demografske karakteristike ispitanika}

Based on collected data, analysis of basic socio-demographic characteristics of the respondents is conducted starting with analysis of age distribution (Chart 1). Analysed data had indicated that the youngest forestry professional in the FB-H is 23 years old, while the oldest employed forestry professional is 65 years old. In average forestry professionals in the FB-H are 42 years old. Similar results were obtained in the research conducted within GovoR project (MUTABDŽIJA, 2013). Based on the results of this and abovementioned research, it can be concluded that population of forestry professionals in the FB-H is relatively young since more than 68 percent of the respondents are between 25 and 50 years old.

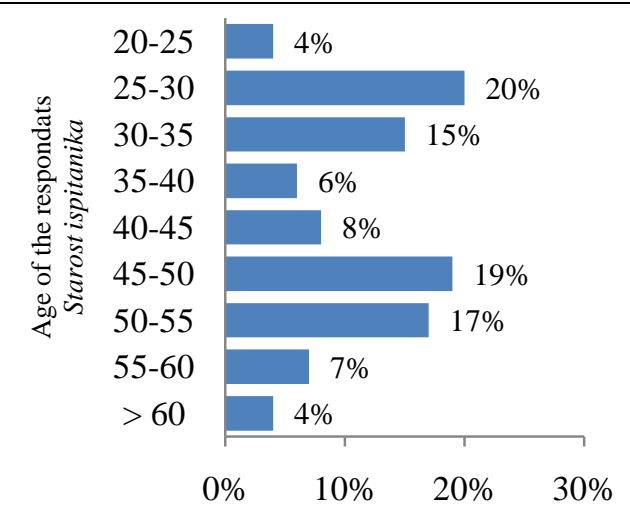

Chart 1. Age distribution of the respondents

Grafikon 1. Starosna struktura ispitanika

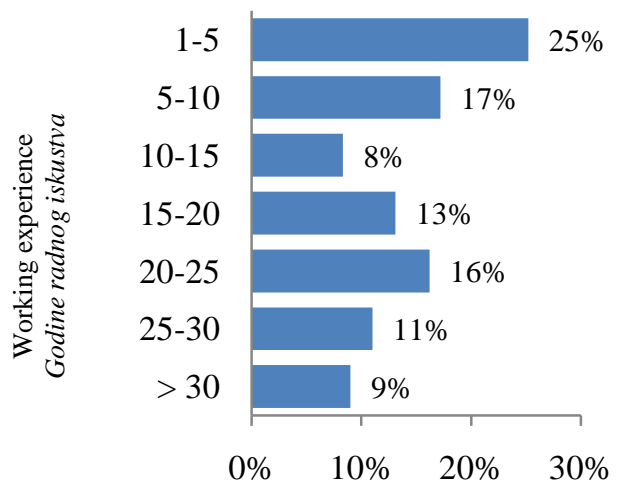

Chart 2. Working experience distribution Grafikon 2. Struktura ispitanika po godinama radnog iskustva

When it comes to the years of working experience, forestry professionals in the FB-H have 15 years of working experience on average (Chart 2). More than 40 percent of the respondents have less than 10 years of working experience. Based on these data, one can conclude that distribution of years of working experience is relatively unfavourable due to the fact that significant number of respondents is at the beginning of career. Such unfavourable distribution indicates lack of new working positions in forest sector of the FB-H.

When it comes to the type of employment institutions, cantonal forest enterprises prevails (82 percent of respondents are employed in cantonal forest enterprises). On the other side, 18 percent of the employed forestry professionals are 
working in public forest administration. These results corresponds to the exact situation in forest sector of the FB-H where most of forestry professionals are employed in public forest companies while chances for new job positions in public forest administration is aggravated due to the dependency on public funding.

\section{Level of awareness of forestry professionals in the FB-H on EUTR and its} requirements - Nivo poznavanja propisa EUTR-a od strane šumarskih stručnjaka u FBiH

The questionnaire had contained 6 questions that are directly examining respondents' level of awareness on EUTR and its requirements. Those questions were designed as closed questions. Respondents had chance to choose one of the given answers (each question had one right answer). Those questions had contained information related to:

- Geographical area which is directly influenced by EUTR and its provisions,

- Main tasks of EUTR,

- Main goal of EUTR,

- Date for beginning of EUTR implementation,

- Relationship between EUTR and other EU and international forest policy processes (e.g. forest certification, FLEGT, CITES etc.).

In order to identify level of awareness on EUTR and its requirements, answers on abovementioned questions were transformed into new variable corresponding to each respondent. Recoded variable showed how much correct answers each respondent gave which enabled detail analysis of level of their awareness. Data on level of respondents' awareness were transformed in ordinal variable with four categories:

- In case when none of the questions were correctly answered, those answers were recoded as "Not at all aware".

- In case when respondents gave one or two correct answers, those answers were recoded as "Slightly aware".

- In case when respondents have three or four correct answers, those answers were recoded as "Somewhat aware".

- In case when respondents gave five or six correct answers, those answers were recoded as "Aware" (Chart 3).

Almost two thirds of the respondents have recognised insufficient number of correct answers (none up to two correct answers) in the questionnaire. Such result indicates that respondents are not aware of basic requirements of EUTR. Furthermore, 12 percent of respondents did not recognise any of the elements of EUTR implementation. It means that, for this category of respondents, appropriate informational forest policy instrument should be designed and applied in order to 


\section{Dženan Bećirović, Sabina Delić, Mersudin Avdibegović, Bruno Marić, Senka Mutabdžija Bećirović, Špela Pezdevšek Malovrh}

increase their level of awareness related to the EUTR. Almost half of the respondents (47 percent) are those that recognised one or two elements of EUTR implementation ("Slightly aware" respondents) while 40 percent of the respondents gave three or four correct answers ("Somewhat aware" respondents). On the other hand, only 1 percent of the respondents recognised most of the elements of EUTR implementation.

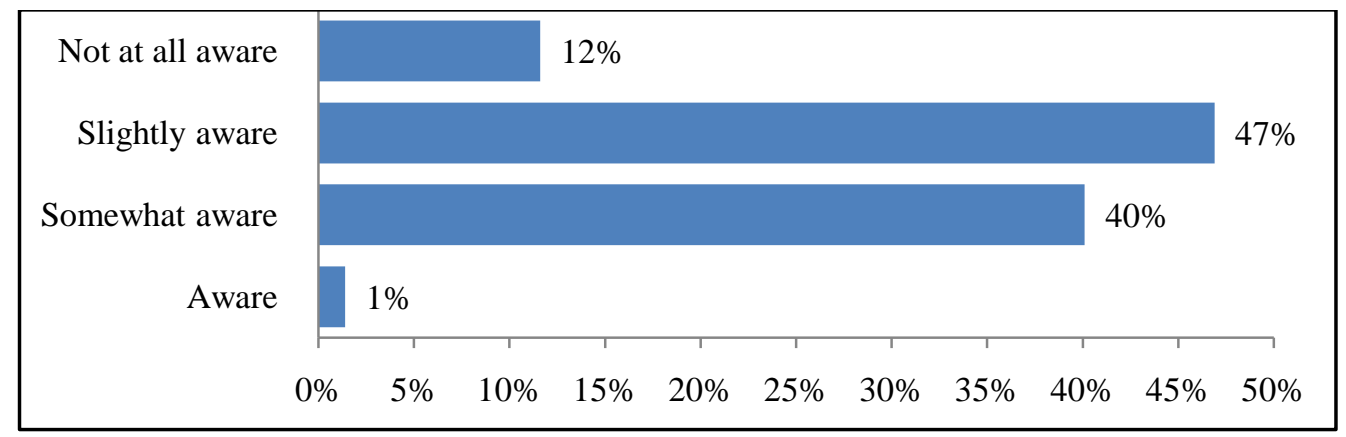

Chart 3. The level of awareness of forestry professionals on EUTR

Grafikon 3. Ocjena nivoa poznavanja propisa EUTR-a od strane šumarskih stručnjaka

Next step of the analysis was referring to the comparison between independent variables (socio-demographic characteristics of the respondents) and level of awareness. In order to implement this analysis, cross-tabulation was used (Chart 4). Results revealed that level of awareness of forestry professionals that are working in public forest administration are belonging to the two middle categories (slightly aware and somewhat aware). Such result indicates that those forestry professionals have certain knowledge about EUTR implementation process (Chart 4a). When it comes to the forestry professionals employed in cantonal forest enterprises, 14 percent of the respondents are not aware on EUTR and its requirements while less than 1 percent of the respondents are aware on EUTR (Chart 4a). The result of cross-tabulation showed that there is significant differences in level of awareness between those respondents employed in public administration and cantonal forest enterprises $\left(\chi^{2}=11,406\right.$, $\mathrm{p}=0,010$ ). Such results lead to the conclusion that this category of the respondents needs more information about EUTR implementation process and potential consequences for forest and wood processing sector in the FB-H. Further analysis revealed that younger respondents (less than 45 years) and those with less than 15 years of working experience are more likely to be "Not at all or slightly aware" on EUTR implementation process compared to elder colleagues and highly experienced ones (Chart $4 \mathrm{~b}$ and $4 \mathrm{c}$ ). The above mentioned results lead to conclusion that design of appropriate informational and educational forest policy instruments is necessary precondition for consistent and effective harmonisation of forest policy in the FB-H with EUTR requirements. Informational instruments should be directed to all respondents that are subjects of this study as well as general public. Purpose of these 


\section{Herzegovina}

instruments would be to raise awareness on negative consequences of illegal activities in forest sector and to inform all actors on need for joint effort on prevention and combat with this problem. On the other hand, educational activities should be designed for those categories of respondents that are not aware on elements of EUTR implementation. Implementation of educational activities should increase capacities of forestry professionals for implementing operational activities that will lead to the effective prevention and combat with illegal activities in forest sector and by that -to the creation of preconditions for effective harmonisation of forest policy in the FB-H with EUTR.

$a$.

$b$.
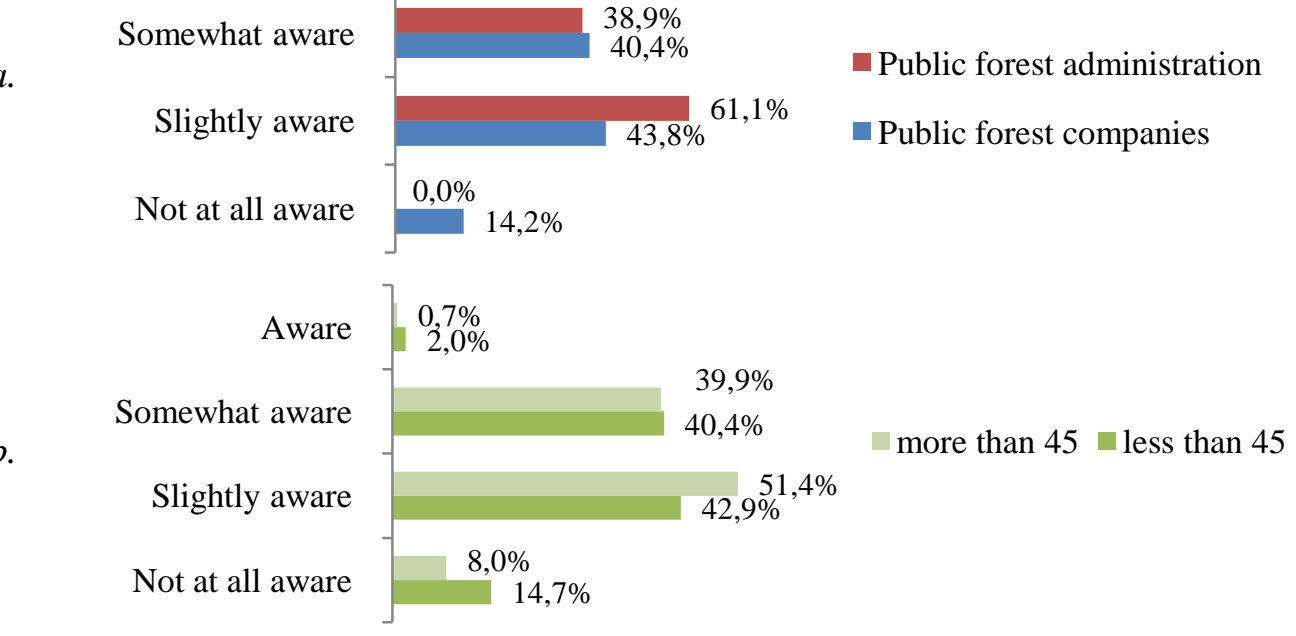

c.

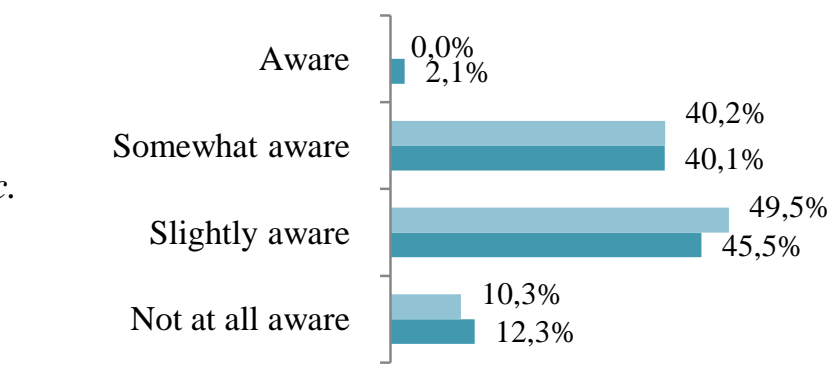

Chart 4. Cross-tabs of independent variables and level of awareness of EUTR

Grafikon 4. Odnos nezavisnih varijabli i nivoa poznavanja propisa EUTR-a

Analysis of forestry professionals' awareness of the EUTR was concluded by creating logistical model in order to identify possible differences in analysed population when it comes to the level of awareness on EUTR and its requirements. In this case, model of logistic regression was not statistically significant $\left(\chi^{2}=0,256\right.$, 
$\mathrm{p}=0,968$ ). In other words - none of the independent variables (age, years of working experience and type of employment institution) had statistically significant influence on respondents in terms of their grouping into those that are aware or not aware of the EUTR requirements. Furthermore, there is relatively high number of respondents that are not aware of EUTR implementation process in analysed population. On the other side, in all categories of respondents there are those who are relatively aware on EUTR implementation process. Such result indicates that those respondents could be responsible for implementation of activities related to harmonisation of forest policy in the FB-H with EUTR.

\section{CONCLUSIONS - Zaključci}

Results presented in this paper revealed that employed forestry professionals in the FB-H have different level of awareness on EUTR implementation process. Furthermore, informational forest policy instruments are needed in order to increase capacities of forestry professionals related to elements of EUTR implementation process. According to the results on differences between certain categories of respondents, one can conclude that level of awareness of forestry professionals in the FB-H needs to be increased. This can be done by appropriate mix of informational (educational) forest policy instruments. Based on the results of this study, forestry professionals which are not informed about EUTR should represent the target audience for implementation of these forest policy instruments. Beside, informational policy instruments could be very useful to the representatives of wood processing industry as well as decision makers responsible for EU integration process. Relevant information related to the basic elements of EUTR implementation process, the establishment of Due diligence system, role of competent authorities and monitoring organisation as well as list of wooden products covered by EUTR, should be integral part of informational and educational materials. On the other side, lack of Forest law in the FB-H as well as relatively high level of illegal activities and corruption in forest sector could lead to denotation of the FB-H as "high risk wood source market" for the EU operators. Such categorisation of the FB-H could result in reduction of competitive advantages of export-oriented wood processing companies and hamper their effort on exporting their wood products to the EU market. Therefore, joint effort on prevention and combat with illegal activities in forest sector involves creation and implementation of mix of forest policy instruments directed toward harmonization of forest policy in the FB-H with EUTR requirements. Comprehensive implementation of forest policy instruments requires active participation of forestry professionals that are aware on complexity of EUTR implementation-process and its influences on forest and wood-processing sectors of the FB-H. 


\section{REFERENCES - Literatura}

AVdibegović, M. (2001): The Application of FSC Principles as External Standards of Forest Certification in Bosnia and Herzegovina, Radovi Šumarskog fakultetaUniverziteta u Sarajevu, Vol. 31, br. 1.

Avdibegović, M., KRILAŠEvić, E., Selmanagić, A. (2006): Collision between Regulations in Forest Law and Environment Related Legislation in the Federation of B-H, IUFRO Division 6, RG 6.13.00 - Social, Economic, Information and Policy Sciences, Proceedings of the 8th International Symposium on Legal Aspects of European Forest Sustainable Development, Department of Forest Law, Faculty of Forestry, Istanbul.

AVDIBEgOVIĆ, M., ŠAKOVIĆ, Š.,KORIČIĆ, Š. (2003): The cross-sectoral dialogue as a basis for definition of internal certification standards in B-H, Proceedings of the First symposium about veterinary, agriculture and forestry in B-H, Faculty of Forestry in Sarajevo, Sarajevo.

Brajić, A., MutabdžıJA, S., Avdibegović, M., Marić, B., BećlRović, Dž., Grašıć, T., Nikolić, V., Nevenić R., Pezdevšek Malovrh, Š. (2011): Forest Related Legislation in Some Western Balkan Countries Referring to Nature Protection Regulations, Radovi Šumarskog fakulteta Univerziteta u Sarajevu, Vol. 41, br. 2.

COMmission OF THE EC (2008): Proposal for a Regulation of the European Parliament and of the Council Laying down the obligations of operators who place timber and timber products on the market, Brussels, [Available at: www.ec.europa.eu].

DILLMAN, D.A. (2007): Mail and Internet surveys: The tailored design method, Second ed., John Wiley \& Sons, New Jersey.

FIELD, A. (2009): Discovery statistic using SPSS, Sage publications Ltd., third edition, London.

MUTABDŽIJA, S. (2013): Cross-sectoral perception of forest governance concept in the Federation of Bosnia-Herzegovina, Final work of the Second cycle of the study, Faculty of Forestry University of Sarajevo, pg. 18.

NuLTY, D. D. (2008): The adequacy of response rates to online and paper surveys: What can be done?, Assessment and Evaluation in Higher Education, Vol. 33, No. 3, June 2008, 301-314. [Available at: www.uaf.edu]

Regional EnVIRONMENTAL Center - REC (2010): Illegal Logging in South Eastern Europe, [available at: www.envsec.org].

TAccoNI, L. (2008): Illegal Logging: Law Enforcement, Livelihoods and the Timber Trade, Earthscan, London.

The EuRopean Parliament and the Council of the EuRopean Union (2010): Regulation (EU) No 995/2010 of the European Parliament and of the Council EUTR, Brussels, [Available at: www.ec.europa.eu]. 
United Nations Office on Drugs and CRime - UNODC (2011): Corruption in B-H Bribery as experienced by the population, Vienna, [Available at: www.unodc.org].

URQUHART, J., COURTNEY, P. (2011): Seeing the owner behind the trees: A typology of small-scale private woodland owners in England, Forest policy and economics, 13 (2011), pp. 535-544.

VANJSKOTRGOVINSKA KOMORA BIH - VTK B-H (2014): The economy of B-H - The proposal for improvement of business environment, Sarajevo, [Available at: www.komorabih.ba].

WORLD WIDE FUND FOR NATURE - WWF (2008): Illegal wood for the European market An analysis of the EU import and export of illegal wood and related products. [Available at: www.wwf-ue-2008.org/download/4/].

\section{SAŽETAK}

Implementacija međunarodnih procesa usmjerenih ka prevenciji i suzbijanju ilegalnih aktivnosti u sektoru šumarstva, u novije vrijeme, postaje dominantan pravac šumarske politike. Prva aktivnost Evropske Unije koja se direktno ticala borbe protiv ilegalne trgovine drvnim proizvodima (EU FLEGT akcioni plan) je pokrenuta 2002. godine. Evropska komisija je kroz niz konsultativnih aktivnosti izrazila odlučnost da aktivno učestvuje u borbi protiv ilegalnih aktivnosti u sektoru šumarstva nastojanjem da se zabrani trgovina proizvodima od drveta ilegalnog porijekla. Tako su, uz podršku Svjetske banke, pokrenute regionalne inicijative za sprečavanje trgovine proizvodima od drveta ilegalnog porijekla poznate pod nazivom FLEGT proces (engl. Forest Law Enforcement, Governance and Trade - Provođenje šumarskih zakona, governance i trgovina). Važan segment u realizaciji FLEGT procesa predstavlja usvajanje pravno obavezujuće uredbe kojom se u državama članicama nastoji zabraniti uvoz proizvoda od drveta ilegalnog porijekla. Uredbom broj 995/2010, poznatijom pod nazivom EU Timber Regulation - EUTR, koja je usvojena 20.10.2010. godine, se posebno naglašava važnost mjera koje trebaju poduzeti poslovni subjekti koji prvi plasiraju proizvode od drveta na tržište Evropske Unije i obaveze država članica. Implementacija EUTR-a utiče na trgovinu proizvodima od drveta na tržištu Evropske Unije kao i na proizvođače za koje države članice Evropske Unije predstavljaju ciljno tržište.

Cilj ovog rada je da se ustanovi nivo poznavanja propisa EUTR-a od strane visokoobrazovanih šumarskih stručnjaka u $\mathrm{FBiH}$. Za potrebe ostvarenja ovog cilja kontaktirano je 435 visokoobrazovanih stručnjaka šumarstva i dostavljen im je upitnik kojim se nastojao utvrditi nivo poznavanja propisa EUTR-a. Rezultati rada su pokazali da je nivo poznavanja propisa EUTR-a od strane šumarskih stručnjaka u FBiH nedovoljan za konzistentno usklađivanje šumarske politike sa propisima EUTR-a. Na osnovu toga se može zaključiti da je neophodno dodatno informisanje, kako šumarskih 
stručnjaka tako i šire javnosti o negativnom uticaju ilegalnih aktivnosti na stanje šumskih resursa, kao i o osnovnim elementima implementacije EUTR-a i njenog potencijalnog uticaja na izvozno orijentirane proizvođače drvnih proizvoda iz $\mathrm{FBiH}$. Pored toga, naglašeno je da bi aktivnosti, kreirane sa ciljem ispunjavanja odredbi EUTR-a mogle značajno uticati na stanje u sektoru šumarstva i stvoriti pretpostavke za efektivnu prevenciju i borbu protiv ilegalnih aktivnosti. 